\title{
A Study of Product Quality of Selected Public and Private Sector Life Insurance Companies
}

\author{
${ }^{1}$ Dr. Harish B. Bapat, ${ }^{2}$ Dr. Vishal Soni, ${ }^{3}$ Dr. Ritu Joshi \\ ${ }^{I}$ Director Management Programs \& Corporate Communications, Vindhya Group, Indore, Approved by AICTE \\ and Affiliated to RGPV, Bhopal and DAVV, Indore, M.P. \\ ${ }^{2}$ Professor and Head, Swami Vivekanand College of Engineering, Indore Approved by AICTE and Affiliated to \\ $R G P V$, Bhopal and DAVV, Indore, M.P \\ ${ }^{3}$ Professor and Head MBA, Truba College of Engineering \& Technology, Approved by AICTE and Affiliated to \\ $R G P V$, Bhopal and DAVV, Indore, M.P
}

\begin{abstract}
The need for insurance is as old as commerce and trading in the civilized world. Risk is inherent to life, commerce, trading etc. The insurance will provide safety to it. Insurance sector has been playing a leading role in the financial system of India. It has also been facilitating an objective to build an efficient, effective and a stable economic environment in India. It also caters to the needs of the both real economy and socio-economic objective of the country. It is making inroads into the interiors of the economy and is being considered as one of the fast developing areas in the Indian financial sector. It has been mobilizing long-term saving through life insurance to support economic growth and also facilitating economic development.

In India after a monopoly of public sector life Insurance company for decades, the sector was opened for the private players in order to bring consumerism in real sense. The healthy competition among these companies has resulted in to better quality, customizations, innovations, choice, value, and affordability of the product offerings. The current study attempts to study the product offerings of largest public sector life insurance Company of India Life Insurance Corporation of India and the private giant ICICI prudential life insurance company Ltd on the aspects of applicability of SERVQUAL dimensions to current product offering and to study and compare the perception of customers in terms of service quality.

The study discovers their present levels of the product offerings on the basis of SERVQUAL dimensions. The study also attempts to compare perceived quality of product offerings of the selected life insurance companies on SERVQUAL dimensions. It is an exploratory research study, which after development of conceptual frame work deploys structured instrument and statistical analysis tools like Eigen value scores and variance to measure the output.

This study shall be helpful to give a wonderful insight to the practicing managers to identify the gap and take leverage by offering the desired quality products.
\end{abstract}

Key words: Quality, SERVQUAL, Life Insurance, Organization, Service

\section{Introduction}

In 1956 nationalization of insurance business was a major milestone in the development of insurance business in India by taking 245 private insurers business.

The Indian insurance market was thrown open to private players in the year 1999 and the Insurance Regulatory and Development Authority (IRDA) was established to regulate the insurance market. After it's opening, the insurance sector has the entry of a number of private players who captured a significant market shares in the life insurance market. The public sector companies have to leverage upon their strengths to give a tough flight to the private sector players.

\section{The Product}

Life Insurance is now the most popular instrument for the planning for the risk of untimely death, the concept has been modified to merge with saving vehicles to create very interesting and apt investment product. Life insurance products have to suit the requirements of customer. The three major concerns of any person could be-Dying too early, living too long Or Living with disability

Life insurance products fundamentally provide for- 1.Risk Cover 2.Investment 3.Heath Cover, 4.Tax saving

There are four main types of insurance policies described as follows.-

1. Term Insurance: Term Insurance pays a death benefit to the legal heirs if the person insured, dies during the term of the policy. Terms insurance plans offer pure risk cover without any element of saving.

2. Whole Life Insurance: The advantage of whole life insurance is that the policy, if kept current, covers you over your entire life, as opposed to term insurance that covers you only for a certain term of years. 
3. Endowment Insurance: Pure endowment is a plan where the benefit is payable to the insured only on survival of the specified term.

4. Annuities: Annuities are a form of pension in which an insurance company makes a series of periodic payments to a person or his or her dependents over a numbers of years, in return for the money paid to the insurance company either in lump or installments.

\section{Public sector Company: Life insurance Corporation of India}

The Life Insurance Corporation of India (LIC) is only one public sector Company in life insurance. It was created on 1st September, 1956, Over 245 insurance companies and provident societies were merged to create the state owned Life Insurance Corporation. It is the largest insurance company in India with an estimated asset value of ₹ 1560481.84 crore (US $\$ 250$ billion). As of 2013 it had total life fund of Rs.1433103.14 crore with total value of policies sold of 367.82 lakh that year.

\section{Growth as a monopoly}

From its creation, the Life Insurance Corporation of India, which commanded a monopoly of soliciting and selling life insurance in India, created huge surpluses.The Corporation, which started its business with around 300 offices, 5.7 million policies and a corpus of INR 45.9 crores (US\$ 92 million as per the 1959 exchange rate of roughly ₹5 for US\$1), had grown to 25,000 servicing around 350 million policies and a corpus of over ₹800000 crore (US\$130 billion) by the end of the 20th century.

\section{Liberalization post $\mathrm{Y} 2 \mathrm{~K}$}

In August 2000, the Indian Government embarked on a program to liberalize the Insurance Sector and opened it up for the private sector. Ironically, LIC emerged as a beneficiary from this process with robust performance, albeit on a base substantially higher than the private sector. In 2013 the First Year Premium compound annual growth rate (CAGR) was $24.53 \%$ while Total Life Premium CAGR was $19.28 \%$ matching the growth of the life insurance industry and also outperforming general economic growth.

\section{Products and services}

LIC offers a variety of insurance products to its customers such as insurance plans, pension plans, unitlinked plans, special plans and group schemes.

\section{Operations}

Today, the LIC had 8 zonal offices, around 109 divisional offices, 2,048 branches and 992 satellite offices and corporate offices; it also has 54 customer zones and 25 metro-area service hubs located in different cities and towns of India. It also has an accessibility of 1,337,064 individual agents, 242 Corporate Agents, 79 Referral Agents, 98 Brokers and 42 Banks for soliciting life insurance business from the public. As on 31 March 2012, LIC had 119,767 employees, out of which 24,295 were women (20\%).

\section{Agency strength}

LIC had 12, 78,234 agents as on 31 March 2012, out of which the number of active agents was 12, $14,111(95 \%) .11$

\section{Private sector Company: ICICI Prudential Life}

ICICI Prudential Life Insurance Company is a joint venture between ICICI Bank, a premier financial powerhouse, and prudential plc, a leading international financial services group headquartered in the United Kingdom. ICICI Prudential was amongst the first private sector insurance companies to begin operations in December 2000 after receiving approval from Insurance Regulatory Development Authority (IRDA).

ICICI Prudential Life's capital stands at Rs. 4,793 crores (as of March 31, 2013) with ICICI Bank and Prudential plc holding $74 \%$ and $26 \%$ stake respectively. For the financial year 2013, the company has garnered total premium of Rs 13,538 crores. The company has assets held over Rs. 77,393.09 crores as on December 31, 2013. For the past decade, ICICI Prudential Life Insurance has maintained its dominant position (on new business retail weighted basis) amongst private life insurers in the country, with a wide range of flexible products that meet the needs of the Indian customer at every step in life.

ICICI Prudential Life offers plans under the following major need categories: Term plans, Wealth plans ,Retirement plans ,Group plans ,Rural plans 
Other private companies that are in life insurance sector are as under:

- AEGON Religare Life Insurance

- Edelweiss Tokio Life Insurance Co. Ltd

- Aviva India

- Shriram Life Insurance

- Bajaj Allianz Life Insurance

- Bharti AXA Life Insurance Co Ltd

- Birla Sun Life Insurance

- Canara HSBC Oriental Bank of Commerce Life Insurance

- Star Union Dai-ichi Life Insurance

- DLF Pramerica Life Insurance

- Future Generali Life Insurance Co Ltd

- HDFC Standard Life Insurance Company Limited

- ICICI Prudential Life Insurance Company Limited

- IDBI Federal Life Insurance

- IndiaFirst Life Insurance Company

- ING Life Insurance

- Kotak Life Insurance

- Max Life Insurance

- PNB MetLife India Life Insurance

- Reliance Life Insurance Company Limited

- Sahara Life Insurance

- SBI Life Insurance Company Limited

- TATA AIA Life Insurance

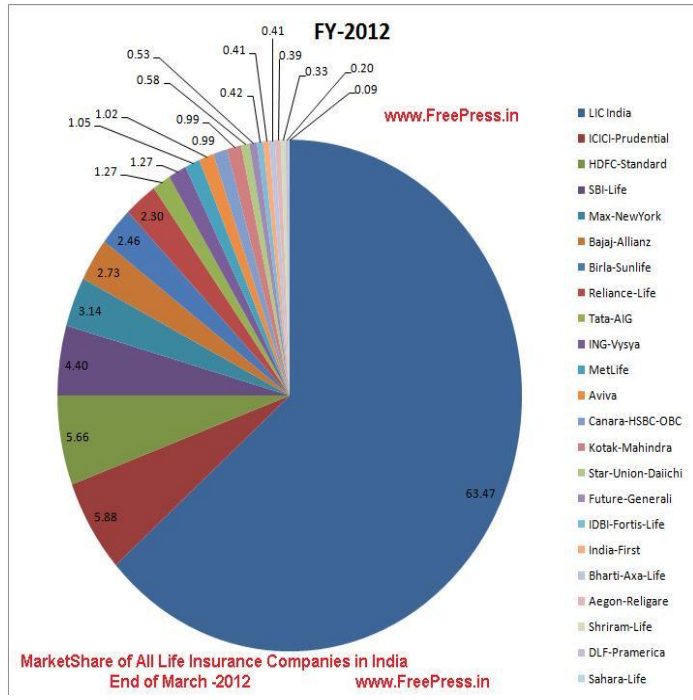

Service quality dimensions: SERVQUAL

By the early 1990s, Parasuraman, A., Valarie Zeithaml, and Leonard Berry had refined the model to the useful acronym RATER:

Tangibility: It includes the appearance of physical elements.

Reliability: It shows the reliability and accurate performance.

Responsiveness: It shows the promptness and helpfulness.

Assurance: It shows the competency, courtesy, credibility and security.

Empathy: It indicates the easy access, good communication, and customer understanding.

General reviews: On marketing of services

\section{Review of Literature}

Dr. C. Rajesham \& Dr. K. Rajendra(2006) reported that the insurance companies are required to come up with multi-benefit policies through innovative products, smart marketing and aggressive distribution with internet facility to increase the quality and volume of insurance business. A study by Parasuram A, Zelthaml V.A. and Berry L.L (1990). reveals that, over two-third of the dissatisfaction is because of perceived 
indifference to their problem or concerns on the part of service providers. Cristopher and Ballntyne (1991) reported that it is the relationship marketing that brings quality, customer service and marketing. Brown and Swartz (1989) reported that the consistent delivery of superior service is the key to the service provider to position themselves more effectively. Parasuraman, Zithmal and Berry (1988) provide a terse definition of service quality. They defined service quality as 'a global judgment, or attitude, relating to the superiority of the service', and explicated it as involving evaluation of the outcome (i.e. what the customer actually receives from the service) and process of the service act (i.e. the manner in which service is delivered). In line with the propositions put forward by Gronroos (1982), Parasuraman, Zithmal and Berry (1985, 1988) posited and operationalised service quality as a difference between consumer expectations of 'what they want' and their perceptions of 'what they get'.

\section{Committed Studies}

Athma. P and kumar. R (2007) in the research paper has identified various products and non-product related factors and their impact on life insurance purchase decision. Girish kumar and eldhose (2008), published in insurance chronicle ICFAI monthly magazine august 2008 in their paper titled "customer perception on life insurance services: a comparative study of public and private sectors", explained the importance of quality services and its significance in raising customer satisfactionlevel.Jayakar (2003) in his study emphasized that new products innovation; distribution and better use of technology are helping the new private life insurers to take market share away from LIC. Bapat Harish et al (2009), revealed in their study named 'life insurance: A Sunrise Sector', that the quality of services will determine the performance of overall sector and not only a single company. Narayan. H. Jai (2009), explained in phase of growing market competition, there is an intense need to go beyond mere efficiency in designing products. Praveen kumar tripathi (2008), in his summer training project conducted a research based study on buying pattern in the insurance industry with a special focus on HDFC standard life insurance.

\section{Importance of the present study}

The study is very important from the point of view of dealing and developing the service marketing culture in the organization especially in the life insurance sector. In the cutting edge competition and liberalization, those companies will survive and lead who will maintain service quality. The present paper is a humble attempt to identify the major factors based on descriptive research design and addresses very important aspect of service quality in life insurance.

\section{Rationale}

After doing rigorous literature review, it is found that there are many studies which have been done on SERVQUAL in the large organizations. The previous studies have also been focused on different aspects of organizational culture and other dimensions of marketing such as internal and interactive marketing. As the reach of the life insurance sector is growing, the researchers inclined to conduct the research in order to know the gap between customers' expectation and product delivery. This study may be help full for the concerning companies to bridge this gap in order to benefit the society at large and build a profitable proposition.

\section{Objectives}

The main objectives of the present study can be figured out as follows.

- To study the applicability of SERQUAL dimension in life insurance companies.

- To measure the perception of customers of selected public and private life insurance service provider in terms of service quality.

- To compare the perception of customers of selected public and private life insurance service provider in terms of service quality.

\section{Research Design}

\section{Research Methodology}

The present research is designed to explore the dimensions of SERVQUAL in the organizations. The conceptual frame work and theoretical linking of the subject is done and the entire research is divided in to the two parts according to the problem definition and objectives. First Tentative norms are applied to the SERVQUAL profile to know the validity and reliability of the instrument. Then it is measured and compared for SERVQUAL dimensions by applying statistical tools. The life insurance companies chosen for the study are LIC of India and ICICI Prudential Life Insurance Company 


\section{Operationalization}

At this level the researcher has put the theoretical concepts to the conceptual frame. It has been found that service quality has been broadly characterized by SERVQUAL.To capture the various dimensions of SERVQUAL a pre tested instrument with extended items to capture two new dimensions namely 'premium' and 'accessibility' have been used. On the basis of above mentioned theoretical understanding the researcher has operationalize the concept.

\section{Variables \\ It can be characterized as consisting of five dimensions of SERVQUAL - \\ 1. Tangibility 2.Reliability 3.Responsiveness 4.Assurance 5.Empathy}

\section{HYPOTHESES}

On the basis of the literature review and the objectives of the study following Null hypotheses have been formulated:-

$\mathbf{H}_{\mathbf{0 1}}$ : There is no significant difference between perception of customers of public and private life insurance service providers in terms of Tangibility.

$\mathbf{H}_{\mathbf{0 2}}$ : There is no significant difference between perception of customers of public and private life insurance service providers in terms of Reliability.

$\mathbf{H}_{\mathbf{0 3}}$ : There is no significant difference between perception of customers of public and private life insurance service providers in terms of Responsiveness.

$\mathbf{H}_{\mathbf{0 4}}$ : There is no significant difference between perception of customers of public and private life insurance service providers in terms of Assurance.

$\mathbf{H}_{05}$ : There is no significant difference between perception of customers of public and private life insurance service provider in terms of Empathy.

$\mathbf{H}_{\mathbf{0 6}}$ : There is no significant difference between perception of customers of public and private life insurance service providers in terms of Premium.

$\mathbf{H}_{\mathbf{0 7}}$ : There is no significant difference between perception of customers of public and private life insurance service providers in terms of accessibility.

\section{Sampling Plan}

Population: It included all those 1) Selected life insurance providers 2) Existing customers for at least last two years in selected companies. The company was selected on the basis of market share.

Sampling Element: The sampling elements of the defined population are existing customers at least for last two years in selected companies and who pays the premium regularly.

Sample size: 70 samples were collected.

\section{Data Collection}

The researcher has used pre tested structured instrument for primary data collection. The questionnaire is used because they have items designed to elicit the information on the research interest and they have protocol for recording the responses. Care has been taken to keep them simple and to avoid leniency, severity, central tendency and halo error (positive and negative questions).A brief introduction of the research is provided in the beginning and the demographics are intentionally placed at last, to maintain the interest of the respondents. Questionnaire was typed and presented to respondents in an arranged manner with likert scale. Pre-tested SERQUAL scale of Parasuraman, Zithmal and Berry is used. In addition to this two more variable (Accessibility \& premium) are added. A pilot test is conducted on very small sample and many errors have been found in the instrument. It is designed and redesigned to avoid the systematic errors. It is also used to see whether the scores are behaving as expected.

\section{Reliability and validity measures}

The indicator scores obtain during the pilot study is subjected to the chronbach alpha test to measure the internal consistency and reliability and it was found that the entire alpha values are more than .7 hence good consistencies is concluded.

\section{Analysis \& Interpretation}

Objective-1:To study the applicability of SERQUAL dimension in life insurance companies To check for the reliability of the data Chronbach's alpha method was used and its value was found to be more then (.7) for all seven variables(Table-1) and which indicates the scale is reliable and consistent. To check the validity (whether the items are capturing the variable) factor analysis is done and it is found that the items are 
highly loaded (more than .5) on a single component and Eigen value is more than 1(Table-2). This showed that SERQUAL dimensions are applicable in Life insurance industry.

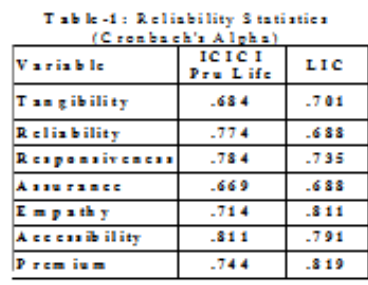

\begin{tabular}{|c|c|c|c|c|c|}
\hline \multirow[t]{2}{*}{ Variable } & & \multicolumn{2}{|c|}{ ICICIDF= Life } & \multicolumn{2}{|r|}{ IIC } \\
\hline & & In itiz & Extractio & $\begin{array}{c}\text { Insitix } \\
\text { i }\end{array}$ & $\begin{array}{c}\text { Fxtractio } \\
\text { a }\end{array}$ \\
\hline \multirow{5}{*}{ Tan gib ility } & $v \Delta R 00001$ & 1.000 & . & 1.000 & 479 \\
\hline & VAR 00002 & 1.000 & .850 & 1.000 & .861 \\
\hline & V $\triangle R 00003$ & 1.000 & .623 & 1.000 & 519 \\
\hline & $\mathrm{V} \triangle \mathrm{R} 00000$ & 1.000 & .700 & 1.000 & .457 \\
\hline & v 4200005 & 1.000 & .512 & 1.000 & .821 \\
\hline \multirow{5}{*}{ R elixbility } & $v \Delta \pi 00001$ & 1.000 & .687 & 1.000 & 479 \\
\hline & $\mathrm{V} A \mathrm{R} 00002$ & 1.000 & .925 & 1.000 & .861 \\
\hline & $v A R 00003$ & 1.000 & .858 & 1.000 & .549 \\
\hline & $v \Delta \pi 00004$ & 1.000 & .574 & 1.000 & .657 \\
\hline & $v \Delta x 0000 s$ & 1.000 & .819 & 1.000 & .821 \\
\hline \multirow{5}{*}{ Rexpositesen } & $v A R 00001$ & 1.000 & .899 & 1.000 & $.8 * 1$ \\
\hline & $\mathrm{V} \triangle \mathrm{R} 00002$ & 1.000 & .701 & 1.000 & .701 \\
\hline & $v 4 \pi 00003$ & 1.000 & .711 & 1.000 & .612 \\
\hline & $V A R 00004$ & 1.000 & 969 & 1.000 & .812 \\
\hline & VAR $0000 \mathrm{~S}$ & 1.000 & .803 & 1.000 & .625 \\
\hline \multirow{3}{*}{ 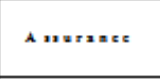 } & $v \Delta R 00001$ & 1.000 & .703 & 1.000 & .699 \\
\hline & $v \Delta R 00002$ & 1.000 & .696 & 1.000 & .6ss \\
\hline & $v A R 00003$ & 1.000 & .859 & 1.000 & .584 \\
\hline \multirow{4}{*}{$E=p a$ th $y$} & $V_{\Delta R 00001}$ & 1.000 & .703 & 1.000 & .565 \\
\hline & $v 4200002$ & 1.000 & .787 & 1.000 & 492 \\
\hline & V $4 R 00003$ & 1.000 & .659 & 1.000 & .809 \\
\hline & $v \Delta R 00004$ & 1.000 & .658 & 1.000 & .543 \\
\hline \multirow{3}{*}{ A ece mibility } & $v \Delta \pi 00001$ & 1.000 & .729 & 1.000 & .785 \\
\hline & $v 4800002$ & 1.000 & .787 & 1.000 & .836 \\
\hline & v $4 \pi 00003$ & 1.000 & .900 & 1.000 & .928 \\
\hline \multirow{3}{*}{ Prem ium } & $v \Delta R 00001$ & 1.000 & .980 & 1.000 & .734 \\
\hline & $v 4200002$ & 1.000 & 940 & 1.000 & .727 \\
\hline & $V A R 00003$ & 1.000 & .951 & 1.000 & .993 \\
\hline
\end{tabular}

Objective-2: To measure the perception of customers of selected public and private life insurance service provider in terms of service quality.

Tangibility

Table 3: Independent Samples Test

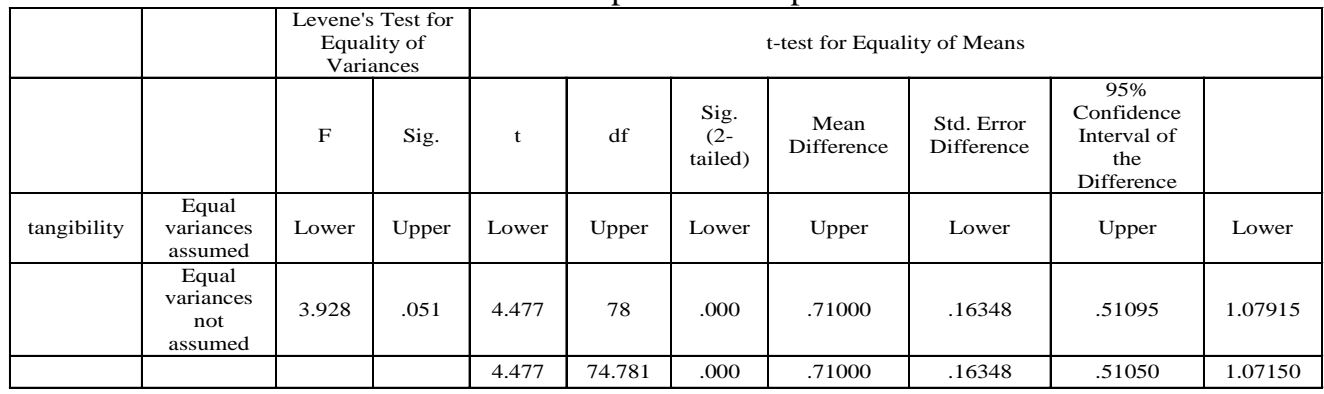

Further table- 3 of the analysis explains the $\mathrm{Z}$ test calculation with a level of significance of .001. $\mathrm{Z}$ test analysis here explains the pattern of the relationship between the independent variables. In the present case the table shows that the $p=.000$ value at $\alpha=.001$ which is highly significant; from this value we can infer that the service quality of LIC and ICICI Pru Life in terms of Tangibility are different.

Reliability

Table-4: Independent Samples Test

\begin{tabular}{|c|c|c|c|c|c|c|c|c|c|c|}
\hline & & \multicolumn{2}{|c|}{$\begin{array}{l}\text { Levene's Test } \\
\text { for Equality of } \\
\text { Variances }\end{array}$} & \multicolumn{7}{|c|}{ t-test for Equality of Means } \\
\hline & & $\mathrm{F}$ & Sig. & $\mathrm{t}$ & df & $\begin{array}{l}\text { Sig. } \\
(2- \\
\text { tailed })\end{array}$ & $\begin{array}{c}\text { Mean } \\
\text { Difference }\end{array}$ & $\begin{array}{l}\text { Std. Error } \\
\text { Difference }\end{array}$ & $\begin{array}{c}95 \% \\
\text { Confidence } \\
\text { Interval of } \\
\text { the } \\
\text { Difference }\end{array}$ & \\
\hline \multirow[t]{2}{*}{ reliabzty } & $\begin{array}{c}\text { Equal } \\
\text { variances } \\
\text { assumed }\end{array}$ & Lower & Upper & Lower & Upper & Lower & Upper & Lower & Upper & Lower \\
\hline & $\begin{array}{c}\text { Equal } \\
\text { variances } \\
\text { not } \\
\text { assumed }\end{array}$ & 3.928 & .051 & 4.477 & 78 & .000 & .74000 & .16528 & .41095 & 1.06905 \\
\hline
\end{tabular}

Further table- 4 of the analysis explains the $\mathrm{Z}$ test calculation with a level of significance of $.001 . \mathrm{Z}$ test analysis here explains the pattern of the relationship between the independent variables. In the present case the table shows that the $\mathrm{p}=.000$ value at $\alpha=.001$ which is highly 
Significant; from this value we can infer that the service quality of LIC and ICICI Pru Life in terms of Reliability are different. The above analysis and interpretation states that the null hypothesis is rejected.

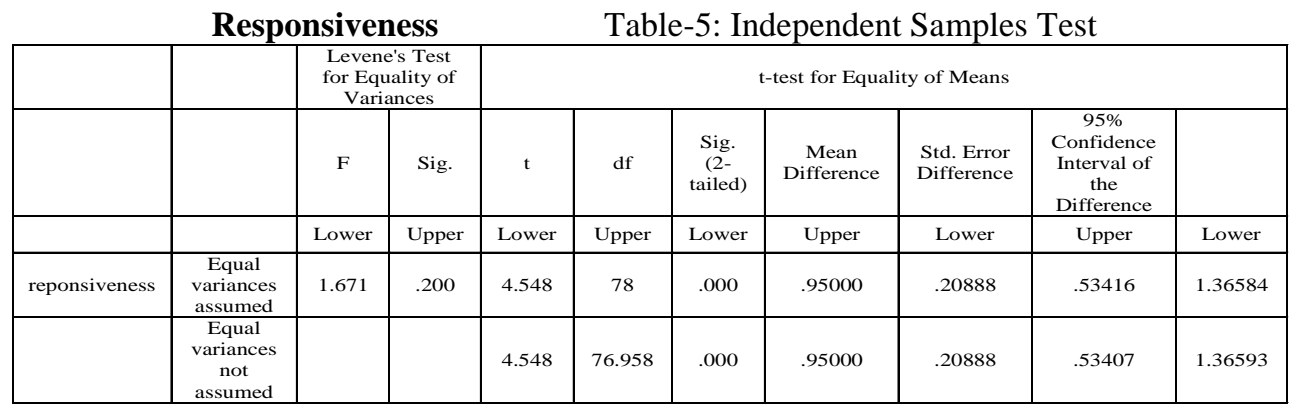

Further table- 5 of the analysis explains the $\mathrm{Z}$ test calculation with a level of significance of .001. $\mathrm{Z}$ test analysis here explains the pattern of the relationship between the independent variables. In the present case the table shows that the $\mathrm{p}=.000$ value at $\alpha=.001$ which is highly significant; from this value we can infer that the service quality of LIC and ICICI Pru Life in terms of Responsiveness are different. The above analysis and interpretation states that the null hypothesis is rejected.

\begin{tabular}{|c|c|c|c|c|c|c|c|c|c|c|}
\hline \multicolumn{4}{|c|}{ Assurance } & \multicolumn{7}{|c|}{ Table-6: Independent Samples Test } \\
\hline & & $\begin{array}{r}\text { Levene } \\
\text { Equ } \\
\text { Var }\end{array}$ & $\begin{array}{l}\text { Test for } \\
\text { ty of } \\
\text { ices }\end{array}$ & \multicolumn{7}{|c|}{ t-test for Equality of Means } \\
\hline & & F & Sig. & $\mathrm{t}$ & df & $\begin{array}{l}\text { Sig. } \\
(2- \\
\text { tailed) }\end{array}$ & $\begin{array}{c}\text { Mean } \\
\text { Difference }\end{array}$ & $\begin{array}{l}\text { Std. Error } \\
\text { Difference }\end{array}$ & $\begin{array}{c}95 \% \\
\text { Confidence } \\
\text { Interval of } \\
\text { the } \\
\text { Difference }\end{array}$ & \\
\hline & & Lower & Upper & Lower & Upper & Lower & Upper & Lower & Upper & Lower \\
\hline assurance & $\begin{array}{c}\text { Equal } \\
\text { variances } \\
\text { assumed }\end{array}$ & 2.722 & .103 & 5.064 & 78 & .000 & .88750 & .17526 & .53858 & 1.23642 \\
\hline & $\begin{array}{c}\text { Equal } \\
\text { variances } \\
\text { not } \\
\text { assumed }\end{array}$ & & & 5.064 & 73.947 & .000 & .88750 & .17526 & .53828 & 1.23672 \\
\hline
\end{tabular}

Further table- 6 of the analysis explains the $\mathrm{Z}$ test calculation with a level of significance of .001 . $\mathrm{Z}$ test analysis here explains the pattern of the relationship between the independent variables. In the present case the table shows that the $\mathrm{p}=.000$ value at $\alpha=.001$ which is highly significant; from this value we can infer that the service quality of LIC and ICICI Pru Life in terms of Assurance are different. The above analysis and interpretation states that the null hypothesis is rejected.

\begin{tabular}{|c|c|c|c|c|c|c|c|c|c|c|}
\hline \multicolumn{4}{|c|}{ Empathy } & \multicolumn{7}{|c|}{ Table-7: Independent Samples Test } \\
\hline & & \multicolumn{2}{|c|}{$\begin{array}{l}\text { Levene's Test for } \\
\text { Equality of } \\
\text { Variances }\end{array}$} & \multicolumn{7}{|c|}{ t-test for Equality of Means } \\
\hline & & $\mathrm{F}$ & Sig. & $\mathrm{t}$ & $\mathrm{df}$ & $\begin{array}{c}\text { Sig. } \\
(2- \\
\text { tailed })\end{array}$ & $\begin{array}{c}\text { Mean } \\
\text { Difference }\end{array}$ & $\begin{array}{l}\text { Std. Error } \\
\text { Difference }\end{array}$ & $\begin{array}{c}95 \% \\
\text { Confidence } \\
\text { Interval of } \\
\text { the } \\
\text { Difference }\end{array}$ & \\
\hline & & Lower & Upper & Lower & Upper & Lower & Upper & Lower & Upper & Lower \\
\hline empathy & $\begin{array}{c}\text { Equal } \\
\text { variances } \\
\text { assumed }\end{array}$ & 2.231 & .139 & 1.994 & 78 & .030 & .33500 & .16797 & .00059 & .66941 \\
\hline & $\begin{array}{c}\text { Equal } \\
\text { variances } \\
\text { not } \\
\text { assumed }\end{array}$ & & & 1.994 & 75.534 & .030 & .33500 & .16797 & .00042 & .66958 \\
\hline
\end{tabular}

Further table- 7 of the analysis explains the $\mathrm{Z}$ test calculation with a level of significance of $.001 . \mathrm{Z}$ test analysis here explains the pattern of the relationship between the independent variables. In the present case the table shows that the $\mathrm{p}=.03$ value at $\alpha=.05$ which is highly significant; from this value we can infer that the service quality of LIC and ICICI Pru Life in terms of Empathy are different. The above analysis and interpretation states that the null hypothesis is rejected. 


\section{Accessibility}

Table-8: Independent Samples Test

\begin{tabular}{|c|c|c|c|c|c|c|c|c|c|c|}
\hline & & \multicolumn{2}{|c|}{$\begin{array}{l}\text { Levene's Test for } \\
\text { Equality of } \\
\text { Variances } \\
\end{array}$} & \multicolumn{7}{|c|}{ t-test for Equality of Means } \\
\hline & & F & Sig. & $\mathrm{t}$ & df & $\begin{array}{l}\text { Sig. } \\
(2- \\
\text { tailed })\end{array}$ & $\begin{array}{c}\text { Mean } \\
\text { Difference }\end{array}$ & $\begin{array}{l}\text { Std. Error } \\
\text { Difference }\end{array}$ & $\begin{array}{c}95 \% \\
\text { Confidence } \\
\text { Interval of } \\
\text { the } \\
\text { Difference }\end{array}$ & \\
\hline & & Lower & Upper & Lower & Upper & Lower & Upper & Lower & Upper & Lower \\
\hline accessibility & $\begin{array}{c}\text { Equal } \\
\text { variances } \\
\text { assumed }\end{array}$ & 2.131 & .133 & 1.594 & 73 & .040 & .33500 & .17797 & .00053 & 69941 \\
\hline & $\begin{array}{c}\text { Equal } \\
\text { variances } \\
\text { not } \\
\text { assumed }\end{array}$ & & & 1.594 & 78.534 & .040 & .33500 & .17797 & .00041 & .67958 \\
\hline
\end{tabular}

Further table- 8 of the analysis explains the $\mathrm{Z}$ test calculation with a level of significance of .05 . $\mathrm{Z}$ test analysis here explains the pattern of the relationship between the independent variables. In the present case the table shows that the $p=.04$ value at $\alpha=.05$ which is highly significant; from this value we can infer that the service quality of LIC and ICICI Pru Life in terms of Accessibility are different. The above analysis and interpretation states that the null hypothesis is rejected.

Premium

Table-9: Independent Samples Test

\begin{tabular}{|c|c|c|c|c|c|c|c|c|c|c|}
\hline & & \multicolumn{2}{|c|}{$\begin{array}{c}\text { Levene's Test } \\
\text { for Equality of } \\
\text { Variances } \\
\end{array}$} & \multicolumn{7}{|c|}{ t-test for Equality of Means } \\
\hline & & vat & Sig. & $\mathbf{t}$ & df & $\underset{\substack{\text { Sig. } \\
\text { (2- } \\
\text { tailed) }}}{ }$ & $\begin{array}{c}\text { Mean } \\
\text { Difference }\end{array}$ & $\begin{array}{l}\text { Std. Error } \\
\text { Difference }\end{array}$ & $\begin{array}{c}95 \% \\
\begin{array}{c}\text { Confidence } \\
\text { Interval of } \\
\text { the } \\
\text { Difference }\end{array} \\
\end{array}$ & \\
\hline & & Lower & Upper & Lower & Upper & Lower & Upper & Lower & Upper & Lower \\
\hline premium & $\begin{array}{c}\text { Equal } \\
\text { variances } \\
\text { assumed }\end{array}$ & 2.456 & .128 & 1.4784 & 76 & .020 & .23500 & .18787 & .00063 & .79941 \\
\hline & $\begin{array}{c}\text { Equal } \\
\text { variances } \\
\text { not } \\
\text { assumed }\end{array}$ & & & 1.4784 & 77.514 & .020 & .43500 & .18787 & .00071 & .57958 \\
\hline
\end{tabular}

Further table- 9 of the analysis explains the $\mathrm{Z}$ test calculation with a level of significance of .05 . $\mathrm{Z}$ test analysis here explains the pattern of the relationship between the independent variables. In the present case the table shows that the $p=.02$ value at $\alpha=.05$ which is highly significant; from this value we can infer that the service quality of LIC and ICICI Pru Life in terms of Accessibility are different. The above analysis and interpretation states that the null hypothesis is rejected.

Objective-3: To compare the perception of customers of selected public and private life insurance service provider in terms of service quality.

The researches has compared the service quality on the basis of SERQUAL model and added two more variables (Accessibility \& Premium). The researcher has compared on the basis of Eigen values. The result is shown in below Table 10.

\begin{tabular}{|c|c|c|c|c|c|}
\hline Factors & Items & $\begin{array}{l}\text { Factor Loading } \\
\text { (ICICI Pru Life) }\end{array}$ & $\begin{array}{l}\text { Factor Loading } \\
\text { (LIC) }\end{array}$ & \begin{tabular}{l}
\multicolumn{2}{l}{ Eigen Value } \\
(ICICI Pru \\
Life)
\end{tabular} & $\begin{array}{l}\text { Eigen Value } \\
\text { (LIC) }\end{array}$ \\
\hline \multirow{5}{*}{ Tangibility } & $\begin{array}{ll}\mathrm{P} 1 \\
\end{array}$ & .733 & .479 & \multirow{5}{*}{2.400062} & \multirow{5}{*}{2.0963751} \\
\hline & $\mathrm{P} 2$ & .850 & .861 & & \\
\hline & P3 & .623 & .519 & & \\
\hline & $\mathrm{P} 4$ & .700 & .457 & & \\
\hline & P5 & .512 & .821 & & \\
\hline \multirow{5}{*}{ Reliability } & \begin{tabular}{|l|l|}
$\mathrm{P} 6$ \\
\end{tabular} & .687 & .479 & \multirow{5}{*}{2.442822} & \multirow{5}{*}{3.063995} \\
\hline & P7 & .925 & .861 & & \\
\hline & \begin{tabular}{|l|l|} 
P8 \\
\end{tabular} & .858 & .549 & & \\
\hline & P9 & .574 & .657 & & \\
\hline & \begin{tabular}{|l|}
$\mathrm{P} 10$ \\
\end{tabular} & .819 & .821 & & \\
\hline \multirow{5}{*}{ Responsiveness } & \begin{tabular}{|l|} 
P11 \\
\end{tabular} & .899 & .841 & \multirow{5}{*}{3.435474} & \multirow{5}{*}{2.651795} \\
\hline & \begin{tabular}{|l|l|} 
P12 \\
\end{tabular} & .701 & .701 & & \\
\hline & P13 & .711 & .622 & & \\
\hline & \begin{tabular}{|l|l|} 
P14 \\
\end{tabular} & .969 & .822 & & \\
\hline & P15 & .883 & .625 & & \\
\hline \multirow[b]{3}{*}{ Assurance } & \begin{tabular}{|l|}
$\mathrm{P} 16$ \\
\end{tabular} & .703 & .699 & \multirow{3}{*}{1.258682} & \multirow{3}{*}{1.716506} \\
\hline & \begin{tabular}{|l|} 
P17 \\
\end{tabular} & .696 & .655 & & \\
\hline & P18 & .859 & .584 & & \\
\hline \multirow{4}{*}{ Empathy } & \begin{tabular}{|l|} 
P20 \\
\end{tabular} & .703 & .565 & \multirow{4}{*}{2.021263} & \multirow{4}{*}{1.510619} \\
\hline & \begin{tabular}{|l|}
$\mathrm{P} 21$ \\
\end{tabular} & .787 & .492 & & \\
\hline & \begin{tabular}{|l|l|} 
P22 \\
\end{tabular} & .689 & .809 & & \\
\hline & P23 & .658 & .543 & & \\
\hline \multirow{3}{*}{ Accessibility } & \begin{tabular}{|l|} 
P24 \\
\end{tabular} & .729 & .985 & \multirow{3}{*}{1.96081} & \multirow{3}{*}{2.079465} \\
\hline & P25 & .787 & .606 & & \\
\hline & \begin{tabular}{|l|} 
P26 \\
\end{tabular} & .900 & .902 & & \\
\hline \multirow{3}{*}{ Premium } & \begin{tabular}{|l|} 
P27 \\
\end{tabular} & .980 & .734 & \multirow{3}{*}{2.748401} & \multirow{3}{*}{2.053334} \\
\hline & \begin{tabular}{|l|} 
P28 \\
\end{tabular} & .940 & .727 & & \\
\hline & P29 & .951 & .993 & & \\
\hline
\end{tabular}

The researcher has found that ICICI Pru Life leads to LIC on Tangibility, Responsiveness, Empathy \& Premium and LIC leads to ICICI Pru Life on Reliability, Assurance \& accessibility. 


\section{Conclusion}

In the cutting edge competition and liberalization world, those companies will survive who continuously work upon and maintain their service quality. The LIC is first and oldest state owned company in life insurance sector. As per the present study, this is a challenge to the private players as it has pre dominance in reliability, assurance and wide network. Private players are trying to overcome it by providing accessibility through internet smart phones and high end up-to-date technology, greater degree of tangibility, effective \& appealing promotional campaign, online services, more personalized \& innovative services, etc. Now the monopoly of LIC is threatened and leading private player like ICICI Pru Life started capturing the market share. The LIC has to take this into consideration and aggressively work upon it in order to excel in other dimensions of SERVQUAL where the private players are marking their significant

The ICICI Pru Life has identified the gap and taken the lead in terms of providing empathy, better response, system and premium. The product customization is good but accessibility and network is less as compare to LIC. The company has to give emphasis on expanding the market coverage. Rewards, incentives and adequate publicity for exemplary conduct, work and innovations should be awarded frequently.

\section{Limitations and scope}

The scope of the present study is limited to the city of Indore and surrounding rural area because of the availability of the resources. For the purpose of studying the SERVQUAL existing customers of life insurance of the companies under study are considered. Further the tenure of association of customers subject to present study is quite stable. Personal interests of customers are not taken into consideration. Implementation and practices of the organizations differ from institute to institute and thus the result may vary. This is a pioneering study on this topic hence limited up to fundamental domain.

\section{Further areas of research}

There remains a scope and gap for further research in this domain of knowledge. It can be extended to regional, national level and to other professionally managed organizations. New variables can be developed taking in to account the other aspects service quality. Further research can be done by developing a suitable model to test the contribution of each variable on dependent variables. In brief, it can be suggested that replication of this study on other randomly selected life insurance organizations, and comparative analysis of life insurance organizations other insurance organizations can be made. Also further study can be done to identify the performance indicators of various categories of life insurance organization with a view to evolve training policy/designs for marketing and product development personnel

\section{References}

[1]. Anand, M. (2002).Indian Insurance Industry. Channelizing growth, Chartered Financial Analyst.

[2]. Dipak Kumar (2008). Research Methodology, Second Edition. Excel Publication.

[3]. Jha, R.N. (2000).Challenges before Insurance Industry, Forum of free Enterprise.

[4]. Kothari, C.R. (2002).Research Methodology, Second edition, New age International Publication.

[5]. Malhotra K. Naresh (2006).Marketing Research, Fifth Edition, Pearson Publication.

[6]. Parasuraman, A., Valarie Zeithaml, and Leonard Berry (1986).SERVQUAL: A Multiple-Item Scale for Measuring Customer Expectations of Service Quality, MA: Marketing Science Institute, Cambridge, and Report No.86-108.

[7]. Rampal M.K. \&. Gupta S.L (2006).Service Marketing, Second Edition, Galgotia Publication, New Delhi.

[8]. Rao, C.S. (2005). IRDA Favors FDI at 49 PC- Business Line.

[9]. Renarajan, Manoj (2006). Telecom Industry- A survey of interaction trends, Decision, IIM, Calcutta, and Vol.27 No.1-4.

[10]. Bapat, Harish and Khasgiwala ,Vishal (2009). Life Insurance: A Sunrise sector, journal of Disha Institute of Sc. \& Mgmt., Raipur, Vol.-1, pp 50-56.

[11]. Keerthi, P. and Vijayalakshmi, R. (2009).A Study on the Expectations and Perceptions of the Services in Private Life Insurance Companies, SMART Journals, Vol. 5, pp.60-65.

[12]. Khan, M.K. (1978).Prospects Of a Career in Life Insurance Business in India - An Analysis, Indian Journal of Marketing, Vol.ume 7(6), pp.23-31.

[13]. Khurana, Sunayna (2008), Customer Preferences in Life Insurance Industry in India,ICFAI University, Journal of Services Marketing, Vol. 6(3), pp. 60-68.

[14]. Kishore, R.B. (2001).A Holistic View of Insurance Reforms and a Blue Print for Strengthening LIC, The Indian Journal, Jan- June, pp. 35.

[15]. Krishan Kumar, S. (2005), LIC Making Inroads into Rural India, Insurance Chronic, pp. 42-49.

[16]. Krishnamurthy, S. (2005).Insurance Sector: Challenges of Competition and Future Scenario, Visalia, Vol. 30(3), pp.23-29.

[17]. Kumar Jagendra (2005), Innovative Environment in Renovated Insurance Industry, The Insurance Times, Vol.25, pp.4.

[18]. Shivanand H. Lengti (2009), Insurance Disputes in India”, ICFAI University, Vol. 7, pp.83.

[19]. Shobit and Shukla, Sanjay (2004), An Empirical Study and Analysis of Failure of Private Insurance Players in Rural Areas, Insurance Chronicle, pp.56-62.

[20]. Smith and Michael, L. (1982), The Journal of Risk and Insurance, Vol. 49( 4), pp. 583-601.

[21]. Yadav, Babita and Tiwari, Anshuja (2012). International Journal of Marketing, Financial Services \& Management Research, Vol.1 (7), pp.106-123.

\section{IRDA Publications}

[22]. Insurance business environment IC 12 - Jan 2007 
[23]. Life assurance IC-33 March 2007

[24]. Life insurance IC-33 - 2007

[25]. Practice of Life assurance IC-02 2006

[26]. Principles of insurance IC-01 Jan 2007

Websites

[27]. http://www.researchandmarkets.com accessed 27.2.14 at 3:40 pm

[28]. http://www.irdaindia.org accessed 27.2.14 at 3:50 pm

[29]. http://www.LIC.co.in/about.htm accessed 28.2.14 at $12.34 \mathrm{pm}$

[30]. http://www.economywatch.com/indianeconomy/indian_insurance_sector accessed 27.2.14 at 3:59 pm

[31]. http://www.indiacore.com/insurance.html 27.2.14 at $4: 05 \mathrm{pm}$

[32]. http://www.iciciprulife.com/public/About-us/About-Us.htm accessed 27.2.14 at 5:47 pm

[33]. http://en.wikipedia.org/wiki/Life_insurance_in_India accessed 27.2.14 at 5:48 pm

[34]. http://www.iciciprulife.com/public/pdf/Investor-Relations/Investor\%20Relations/Key_business_indicators_Q1_2014.pdf accessed 27.2.14 at 5:48 pm

[35]. Share of life insurance companies in India retrieved from http://freepress.in/insurance/market-share-of-all-life-insurance-companiesindia/ accessed 27.2 .14 at $6.25 \mathrm{pm}$

\section{Biographical Notes}

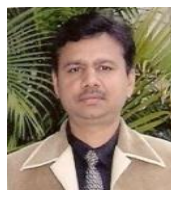

Dr. Harish B. Bapat (Director Management programs \& Corporate Communications, Vindhya Group, Indore)

Dr. Harish B. Bapat is a dual post-graduate in Management and Law From the prestigious Devi Ahilya University, Indore (M.P.).He has done full time residential FDP from Indian Institute of Management (Indore). He did his Ph.D. in Management from IMS,DAVV,Indore(M.P.) The topic of his Doctoral research was "A Study of Marketing Practices in Professional Education" He is currently Director(Academics) \& Head(Corporate Communications) at Vindhya Group of Institutes. Prior to joining Vindhya he taught at various technical and management education institutes. He had also worked as HOD (Management Programs) at Wigan\& Leigh College U.K. (Indore Campus).He has a vast teaching experience and his teaching and research interests are in Marketing, Business Law, IPR's, and Operations Management etc.

$\mathrm{He}$ has authored various case studies and research papers on diversified topics. His case study 'Fresh Revolution' based on Reliance Fresh has received special mention at IIMC. Another case study developed by him is on Tata's Nano which was selected for presentation at Welingkar institute of Management, Mumbai it was among top four case studies selected from all over India. He has conducted several workshops and faculty development programs at various prestigious management Institutes.

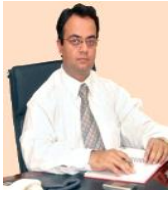

Dr. Vishal Soni -Professor and Head of Department-MBA, Swami Vivekanand College of Engineering, Indore, M.P, India. Dr. Soni is an MBA and has Ph.D. in Management from Institute of Management Studies (IMS) DAVV, Indore. Dr. Soni has 14 plus years of academic and corporate experience. He has worked with leading concerns such as EBotTechnosoft, Shreya Life Sciences, MRSCPS, PIPS\& SIMS \& PGOI. Teaching, Coaching, Mentoring and Corporate Training are the interest area for him. Dr. Vishal has been interviewed by AAJ Tak \& Zee TV. Various research papers are to his credit. Dr.Vishal Soni is a well-known coach \& mentor for various organizations and has conducted many National Seminars, Conferences, Faculty Development Programs, Executive Development Programs, Workshops, Entrepreneurship Development Programs and Management Development Programs.

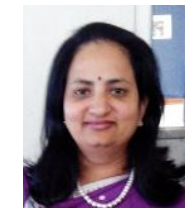

Dr. Ritu Sanjay Joshi (Head Of Department, TRUBA College Of Engineering and Technology) Dr. Ritu Sanjay joshi is Ph.D, MBA from DAVV, Indore and BCS from Pune University, Pune. She is having 12 years of academic experience and 6 years of industrial experience in Pune and Indore. Currently, she is working with Truba College of Engineering And Technology, Indore, as Head, Department of Management Studies. She has taught diverse set of subjects like Organizational Behaviour, Human Recourse Management, Social Psycology, Compensation Management, Entrepreneurship, etc. 